\begin{tabular}{|c|c|c|}
\hline $\begin{array}{l}\text { An International Biannual Open Access } \\
\text { Peer-Reviewed/Refereed Journal } \\
\text { JOURNAL OF GLOBAL RESOURCES } \\
\text { Published by : ISDESR, Jaipur, India }\end{array}$ & 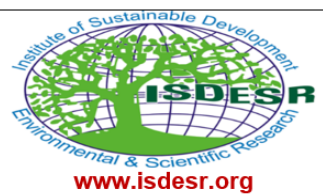 & $\begin{array}{r}\text { ISSN: } 2395-3160 \text { (Print) } \\
\text { ISSN: } 2455-2445 \text { (Online) } \\
\text { January 2022, Volume 08 (01) } \\
\text { DOI Prefix: } 10.46587 / J G R\end{array}$ \\
\hline
\end{tabular}

06

\title{
CHANGES IN LEVELS OF MAIZE PRODUCTIVITY IN HIMACHAL PRADESH: 1990-91 TO 2014-15
}

\author{
Shivjeet Kaur, ${ }^{1}$ Jaswinder Kaur ${ }^{2}$ and K. S. Sohal ${ }^{3}$ \\ ${ }^{1}$ Assistant Professor, Research ${ }^{2}$ Scholar and ${ }^{3}$ Former Professor and Head, \\ Department of Geography, Punjabi University, Patiala (Punjab) India \\ Email: kuljitsinghsohal@yahoo.co.in
}

How to cite this paper:

Shivjeet Kaur, Jaswinder Kaur and Sohal. K. S. (2022) changes in levels of maize productivity in Himachal Pradesh:1990-91 to 2014-15, Journal of Global Resources, Vol. 08 (01)

\section{DOI:}

10.46587/JGR.2022.v08i01.006

Received: 22 Sep. 2021

Reviewed: 04 Oct. 2021

Revised: 05 Nov. 2021

Final Accepted: 14 Nov. 2021

OPEN $O$ A C CES S

Freely available Online

www.isdesr.org

\begin{abstract}
The chief objective of the present study is to reveal spatial patterns of maize productivity and Changes in Himachal Pradesh during 1990-91 to 2014-15. For achieving this purpose, the study is divided into three parts. First part deals with spatial patterns of maize productivity. It is found that the index value of maize productivity varied from minimum of 47.55 percent in Spiti tehsil to 155.90 percent in Churah tehsil in 1990-91. While in 2002-03, it varied from 47.45 percent in Lahaul tehsil to 143.14 percent in Churah tehsil. Whereas in 2014-15, it is lowest of 47.97 percent in Spiti tehsil and highest of 141.51 percent in Churah tehsil. It is also observed that in all time periods, magnitude of maize productivity starts declining from west to east. In second part, it is found that in Himachal Pradesh, the highest index value of maize productivity has declined from 150.90 percent to 141.15 percent during 1990-91 to 2014-15 and registered overall negative change of 8.39 percent index value. Whereas the lowest index value of maize productivity has increased from 47.55 percent in 1990-91 to 47.97 percent in 2014-15 and experience 0.42 percent increase in lowest index value of maize productivity during study period, thus the gap between high and low magnitude of maize productivity has minimized which shows that sign of healthy maize cultivation. In third part, major problems are identified and suggestions are made to solve these problems for increasing the maize productivity in the state. The present study is empirical in nature and based on secondary sources of data. Three time periods are taken and averages are derived for each time period, because 1990-91 is the year of liberalization era and 2002-03 and 2014-15 are post liberalization period. Singh (1976), technique is used for deriving the results and choropleth method is applied for mapping the results.
\end{abstract}

Key words: Productivity, Yield Index, Patterns, Magnitude, Index Value, Minimized. 


\section{Introduction}

The term crop productivity is used in different meanings. Sometimes, it defines as output, inputoutput ratio in relation to land, labour and capital employed in agriculture. It is much accepted view that it is the ability of a production system that how it is more economically efficient. Thus, crop productivity means the measure of efficiency of an agricultural production system which employs land, capital and labour (Saddiqui \& Taufique, 2005). It is the off-spring of actions, reactions and interactions among various physical and non-physical factors. It is also a dynamic concept, because crop productivity increases with modification of natural environment and development in socio-economic environment i.e., extent of irrigation, farm mechanization, improved verities of seeds, consumption of chemical fertilizers, agricultural infrastructure, marketing facilities, road density, agricultural research and extension services, government policies, etc. (Singh, 1976 and Singh,1998). Hussain (2009) has argued that "crop productivity / agricultural productivity" is the product of interactions among physical, socio-economic and cultural factors. Thus, to overcome the requirement of ever-increasing demand of food grains, it becomes necessary to raise crop productivity. Being dynamic concept, it can increase or decreases over time. Hence, if the natural environment is favorable but socio-economic factors are less developed, then magnitude will be moderate but if the physical and non-physical environments are unfavorable, the crop productivity would be low and vice-versa. Sohal (2004), stated that occurrences of changes in either physical factors or socio-economic environment affect the levels of crop-productivity. Moreover, its study is vital for identifying regions of high, moderate and low agricultural / crop productivity. Thus, all these developments will certainly help in minimizing the gap between agricultural highly developed and lagging behind regions. The measurement of agricultural productivity enables a comparison of relative performance of farmers between farms, between the types of farming and between geographical regions. A comparison of crop productivity goes on to the heart of economic performance and can also provide guidance for planning and development decisions (Dutta, 2012), (Prasad and Tripathi, 2008), Ali and Ali (2007). Crop productivity is a component of regional development, because higher levels of development are associated with higher levels of agricultural / crop productivity and vice versa (Munir, 1988), Chatterji and Maitreya, 1964).

\section{Study Area}

Himachal Pradesh has 1.69 percent of India's total reporting area and is situated in north-west of the country. Its longitudinal and latitudinal extent lie between $75^{\circ} 40^{\prime} 55^{\prime \prime} \mathrm{E}$ longitudes to $79^{\circ} 04^{\prime} 20^{\prime \prime}$ E longitudes and $30^{\circ} 22^{\prime} 44^{\prime \prime} \mathrm{N}$ latitude to $33^{\circ} 12^{\prime} 40^{\prime \prime} \mathrm{N}$ latitude. Its mean minimum annual temperature is $-4^{\circ} \mathrm{C}$ and mean maximum annual temperature of $30^{\circ} \mathrm{C}$. Average annual precipitation of Himachal Pradesh ranges from $700 \mathrm{~mm}$. to $3000 \mathrm{~mm}$. According to 2011 census its total population is $68,56,509$ persons. It has 85 tehsils and 12 districts.

\section{Objectives}

- To know the spatial patterns of maize productivity during 1990-91, 2002-03 and 2014-15.

- To find out changes in maize productivity during study period.

- To identify factors affecting changes in maize productivity.

\section{Methodology and Sources of Data}

The present study is empirical in nature and based on secondary sources of data. Three time periods are taken and averages are derived for each time period. After reviewing the other techniques of productivity, it is found that Singh (1976), technique is more useful, because its results are more valid as compare to other techniques. Thus, Singh (1976), technique is used for deriving the results and choropleth method is applied for mapping the results. Singh (1976) technique is as follow: 


$$
C p_{i}=\frac{C_{i}+Y_{i}}{2}
$$

$\mathrm{Cp}_{\mathrm{i}}=$ Stands for Crop Productivity Index.

$\mathrm{C}_{\mathrm{i}}=$ Stands for Concentration Index

$Y_{i}=$ Stands for Yield Index.

The crop concentration index of maize is calculated by using following formula:

$$
C_{i}=\frac{C_{p e}}{C_{p r}} \times 100
$$

$\mathrm{C}_{\mathrm{i}}=$ Concentration index.

$\mathrm{Cp}_{\mathrm{e}}=$ Percent area of crop in an enumeration unit.

$\mathrm{Cp}_{\mathrm{r}}=$ Percent area of crop in the entire region.

While the formula for calculating maize yield index is as below:

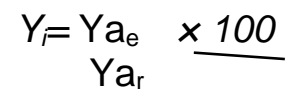

$Y_{i}=$ Maize yield index.

$\mathrm{Ya}_{\mathrm{e}}=$ yield in an enumeration unit.

$\mathrm{Ya}_{\mathrm{r}}=$ yield of crop under entire region.

By using the above-mentioned technique, the patterns of maize crop productivity and changes are individually discussed for the years 1990-91, 2002-03, 2014-15 and changes in this paper.

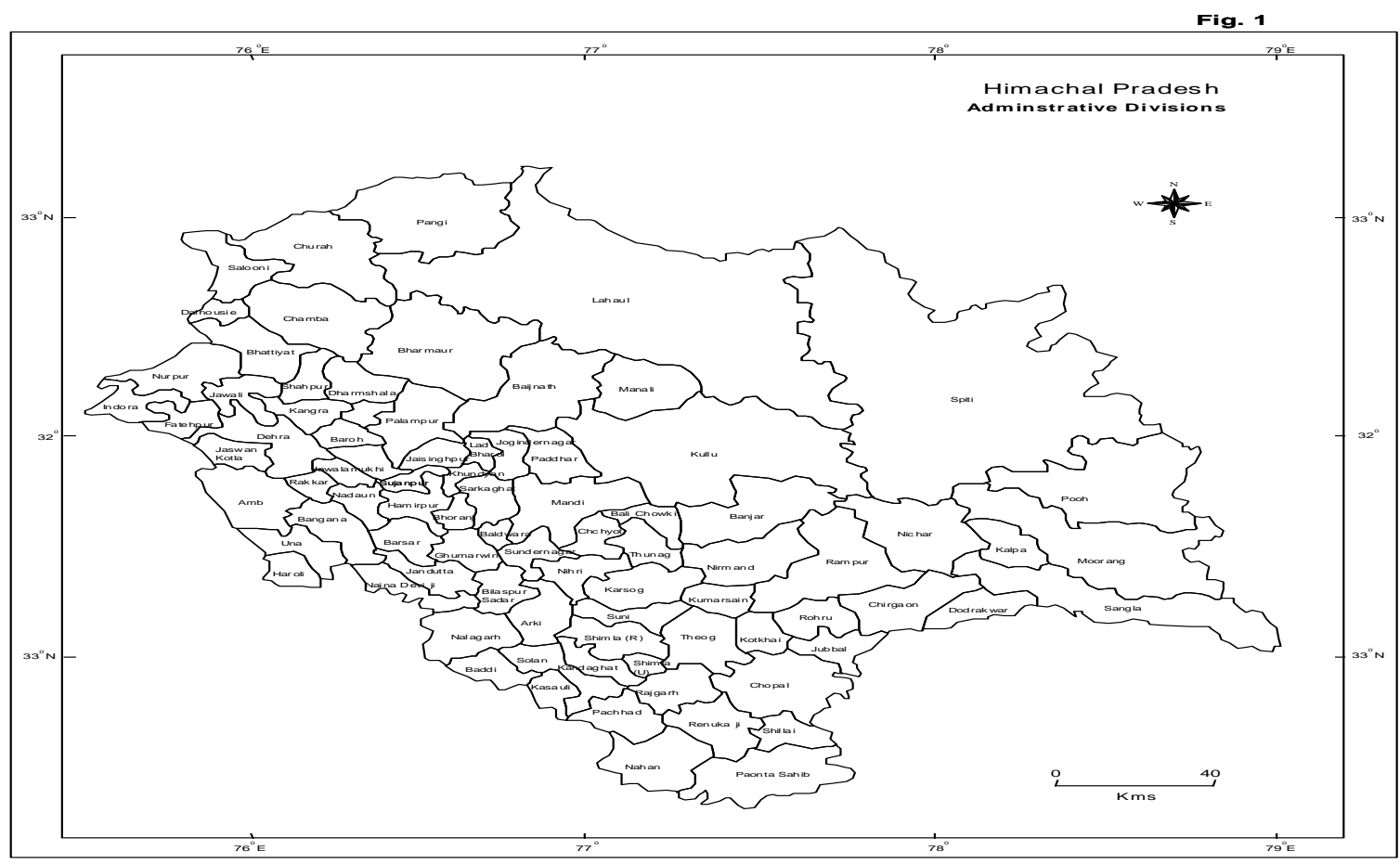

Source: Census of India, 2011

The spatio-temporal changes in maize productivity are discussed as follows:

\section{A. Levels of Maize Productivity: 1990-91}

In Himachal Pradesh, the index value of maize productivity varied from 47.55 percent in Spiti tehsil to 155.90 percent in Churah tehsil during 1990-91, which reflected high spatial variations in the levels of maize productivity. For knowing factors responsible for spatial variations in levels of maize productivity fig. 2 is mapped which displays the following three categories:

1. Category of High Magnitude ( $>115$ index value):

There were 21 tehsils and 24.71 percent of total occurrences in this category. It found in two belts. First belt lied in four tehsils of Chamba district namely Churah, Chamba, Salooni and Dalhousie. Here, the concentration index of maize is very high as well as the yield index. These were 
traditionally maize growing areas of this category. In the case of second belt which is elongated in shape and run from central-western parts to southern parts covering 17 tehsils of Sirmaur, Solan, Bilaspur Sadar, Hamirpur and Mandi district. These tehsils were Bilaspur Sadar, Jandutta, Barsar, Nadaun, Sujanpur, Rakkar, Sundernagar, Kasauli, Baddi, Solan, Arki, Pacchad, Rajgarh, Nahan, Paonta Sahib, Renuka ji and Shillai. All these tehsils were also major maize growing areas, where due to favorable geo-climatic and socio-economic conditions, farmers preferred maize cultivation and at the same time soils were also fertile, which helped in increasing the yield per unit area. Hence, owing to all these factors, this belt had also high magnitude of maize productivity.

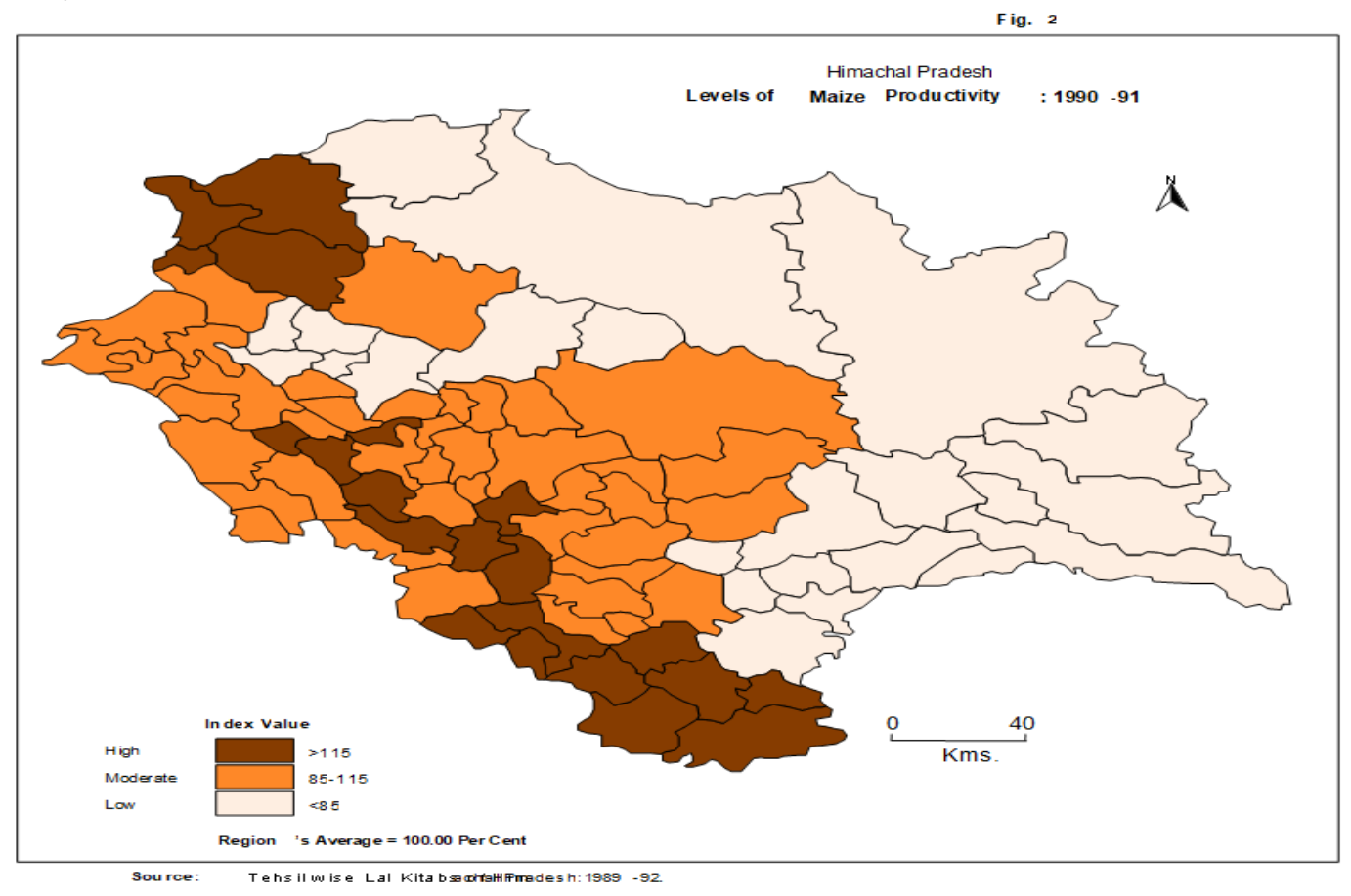

\section{Category of Moderate Magnitude (85-115 index value):}

41 tehsils formed this category which contained 48.23 percent of total occurrences. Here, index value varied between 85-115 and these were also important maize growing areas. It had one belt and one patch. The belt of this category had 40 tehsils namely Bhattiyat, Nurpur, Indora, Jawali, Fatehpur, Dehra, Jaswan Kotla, Jawalamukhi, Khundiyan, Baroh, Jaisinghpur, Kullu, Banjar, Nirmand, Mandi, Sarkaghat, Paddhar, Jogindernagar, Lad-Bharol, Sandhol, Baldwara, Thunag, Bali-Chowki, Chchyot, Karsog, Nihri, Suni, Shimla (R), Shimla (U), Theog, Kandaghat, Una, Amb, Bangana and Haroli. The patch of this category covered Bharmaur tehsil of Chamba district. Here, maize concentration index is high in majority of the tehsils, but yield index varied from low to moderate because of poor irrigation facilities.

\section{Category of Low Magnitude ( $<85$ index value):}

It comprised of 23 tehsils and covered districts of Lahaul \& Spiti, Kinnaur and eastern parts of Shimla and some tehsils of Kullu, Chamba and Kangra districts. The reasons for low magnitude of maize productivity in tehsils of Pangi, Lahaul, Spiti, Manali, Kalpa, Moorang, Pooh, Nichar, Sangla, Rampur, Kumarsain, Kotkhai, Jubbal, Rohru, Chopal, Chirgaon and Dodrakwar were heavy snowfall during summers, mountainous terrain, significant area under fruits, vegetables and wheat. While dominance of rice cultivation was responsible in tehsils of Baijanth, Palampur, Dharmsahala, Shahpur, Kangra and Nagrota Bagwan. In this category area under maize cultivation was very low which was responsible for low concentration of maize productivity, while the yield index was moderate and ultimately resulted into low magnitude of maize productivity. 
Table 01: Levels of Maize Crop Productivity: 1990-91 to 2014-15

\begin{tabular}{|c|c|c|c|c|c|c|c|c|c|}
\hline \# & Tehsils & $1990-91$ & $2002-03$ & 2014-15 & $\#$ & Tehsils & $1990-91$ & 2002-03 & 2014-15 \\
\hline 1 & Bilaspur Sadar & 116.18 & 110.5 & 85.33 & 44 & Spite & 47.55 & 37.46 & 47.97 \\
\hline 2 & Jandutta & 115.03 & 124.27 & 131.86 & 45 & Mandi & 107.99 & 116.63 & 92.48 \\
\hline 3 & Naina Devi ji & 106.82 & 94.16 & 85.07 & 46 & Sundernagar & 118.08 & 121.32 & 106.98 \\
\hline 4 & Ghumarwin & 107.64 & 116.25 & 120.39 & 47 & Sarkaghat & 93.84 & 98.78 & 85.39 \\
\hline 5 & Pangi & 68.29 & 64.63 & 55.16 & 48 & Jogindernagar & 85.27 & 92.58 & 85.18 \\
\hline 6 & Churah & 150.9 & 143.14 & 141.51 & 49 & Karsog & 100.57 & 117.04 & 112.21 \\
\hline 7 & Chamba & 136.28 & 116.5 & 131.96 & 50 & Chchyot & 108.38 & 120.47 & 117.04 \\
\hline 8 & Salooni & 130.28 & 124.27 & 117.16 & 51 & Thunag & 96.49 & 115.1 & 95.16 \\
\hline 9 & Dalhousie & 130.09 & 121.29 & 101.65 & 52 & Baldwara & 93.68 & 98.97 & 86.24 \\
\hline 10 & Bhattiyat & 108.66 & 115.46 & 107.9 & 53 & Bali Chowki & 102.19 & 117.76 & 117.31 \\
\hline 11 & Bharmaur & 102.27 & 91.59 & 48.55 & 54 & Sandhol & 102.3 & 93.6 & 88.67 \\
\hline 12 & Hamirpur & 113.34 & 123.1 & 133.98 & 55 & Paddhar & 111.96 & 117.84 & 104.38 \\
\hline 13 & Bhoranj & 90.52 & 85.62 & 102.59 & 56 & Nihri & 104.21 & 123.99 & 112.36 \\
\hline 14 & Barsar & 115.91 & 119.24 & 115.29 & 57 & Lad-Bharol & 90.8 & 85.26 & 85.95 \\
\hline 15 & Nadaun & 117.22 & 120.15 & 115.91 & 58 & Rampur & 68.06 & 73.67 & 60.06 \\
\hline 16 & Sujanpur & 148.63 & 119.21 & 116.89 & 59 & Kumarsain & 79.14 & 85.08 & 55.67 \\
\hline 17 & Baijnath & 68.04 & 52.45 & 47.42 & 60 & Suni & 97.53 & 91.8 & 56.53 \\
\hline 18 & Palampur & 71.85 & 63.87 & 60.55 & 61 & Shimla $(\mathrm{R})$ & 98.53 & 105.99 & 85.62 \\
\hline 19 & Jaisinghpur & 99.33 & 98.86 & 98.61 & 62 & Shimla $(U)$ & 97.14 & 104.51 & 85.57 \\
\hline 20 & Dharmshala & 63.26 & 54.1 & 50.34 & 63 & Theog & 89.94 & 85.21 & 59.89 \\
\hline 21 & Shahpur & 60.31 & 61.07 & 56.21 & 64 & Kotkhai & 72.58 & 61.39 & 49.88 \\
\hline 22 & Nurpur & 85.47 & 94.5 & 93.91 & 65 & Jubbal & 64.94 & 70.52 & 49.58 \\
\hline 23 & Indora & 85.49 & 90.61 & 86.12 & 66 & Rohru & 69.53 & 71.74 & 51.36 \\
\hline 24 & Jawali & 95.57 & 95.3 & 94.8 & 67 & Chirgaon & 60.32 & 69.41 & 57.99 \\
\hline 25 & Fatehpur & 92.3 & 90.8 & 89.86 & 68 & Dodrakwar & 52.27 & 57.69 & 51.53 \\
\hline 26 & Dehra & 106.43 & 99.97 & 99.75 & 69 & Chopal & 79.46 & 80.25 & 72.87 \\
\hline 27 & Jaswan Kotla & 106.61 & 97.05 & 86.48 & 70 & Nahan & 116.16 & 99.7 & 104.89 \\
\hline 28 & Rakkar & 117.36 & 117.53 & 120.75 & 71 & Paonta Sahib & 115.97 & 89.53 & 85.79 \\
\hline 29 & Jawalamukhi & 109.96 & 103.97 & 105.82 & 72 & Pachhad & 115.49 & 85.23 & 85.71 \\
\hline 30 & Khundiyan & 99.29 & 97.74 & 99.1 & 73 & Rajgarh & 115.37 & 85.78 & 85.43 \\
\hline 31 & Kangra & 72.16 & 68.88 & 63.07 & 74 & Shillai & 120.95 & 102.53 & 107.65 \\
\hline 32 & NagrotaBagwan & 78.69 & 65.43 & 57.46 & 75 & Renuka ji & 115.33 & 94.5 & 90.33 \\
\hline 33 & Baroh & 97.77 & 91.69 & 64.29 & 76 & Solan & 120.95 & 90.78 & 93.08 \\
\hline 34 & Kapla & 59.21 & 57.68 & 50.88 & 77 & Nalagarh & 103.4 & 87.96 & 85.61 \\
\hline 35 & Moorang & 55.05 & 55.18 & 52.07 & 78 & Kasauli & 115.86 & 99.33 & 97.35 \\
\hline 36 & Pooh & 49.1 & 50.68 & 48.73 & 79 & Baddi & 115.16 & 92.04 & 98.11 \\
\hline 37 & Nichar & 56.57 & 57.67 & 55.04 & 80 & Arki & 122.67 & 94.91 & 105.14 \\
\hline 38 & Sangla & 62.26 & 52.39 & 50.19 & 81 & Kandaghat & 106.17 & 86.74 & 92.05 \\
\hline 39 & Kullu & 86.98 & 94.44 & 125.53 & 82 & Una & 111.15 & 92.19 & 102.19 \\
\hline 40 & Manali & 80.26 & 88.7 & 94.77 & 83 & $A m b$ & 108.81 & 110.02 & 109.2 \\
\hline 41 & Banjar & 88.36 & 103.01 & 115.44 & 84 & Bangana & 111.43 & 109.09 & 108.8 \\
\hline 42 & Nirmand & 91.88 & 101.43 & 104.15 & 85 & Haroli & 110.95 & 99.68 & 100.82 \\
\hline 43 & Lahaul & 50.26 & 37.45 & 50.39 & & $\begin{array}{l}\text { Region's } \\
\text { Average }\end{array}$ & 100.00 & 100.00 & 100.00 \\
\hline
\end{tabular}

Source: Tehsil Wise Lal Kitabs of Himachal Pradesh: 1989-92, 2001-04 and 2013-16.

\section{B. Levels of Maize Productivity: 2002-03}

In 2002-03, index value of crop productivity was highly variable because it ranged from 47.45 percent in Lahaul tehsil to 143.14 percent in Churah tehsil in the study region. To know its distributional pattern and factors responsible for an attempt is made with the help of fig. 3 and table which show the following three categories:

\section{Areas of High Magnitude of Maize Productivity ( $>115$ index value):}

It had 20 tehsils which comprised of 23.53 percent of total occurrences. There were two belts of this category. First belt lied in central parts containing 15 tehsils namely Jandutta, Ghumarwin, Hamirpur, Barsar, Nadaun, Sujanpur, Rakkar, Paddhar, Mandi, Sundernagar, Karsog, Nihri, Thunag, Bali-Chowki and Nihri. These areas had favorable both geo-climatic conditions and 
socio-economic environment for maize productivity. Here, both indices of concentration and yield were recorded high which resulted into high levels of maize concentration. Second belt was confined to extreme north-western parts of Chamba district namely Churah, Chamba, Salooni, Dalhousie and Bhattiyat. Here, low to moderate gradient of land, high rainfall, lack of irrigation facilities, traditionally maize growing areas, stapple food, etc. were responsible for high index value of maize productivity.

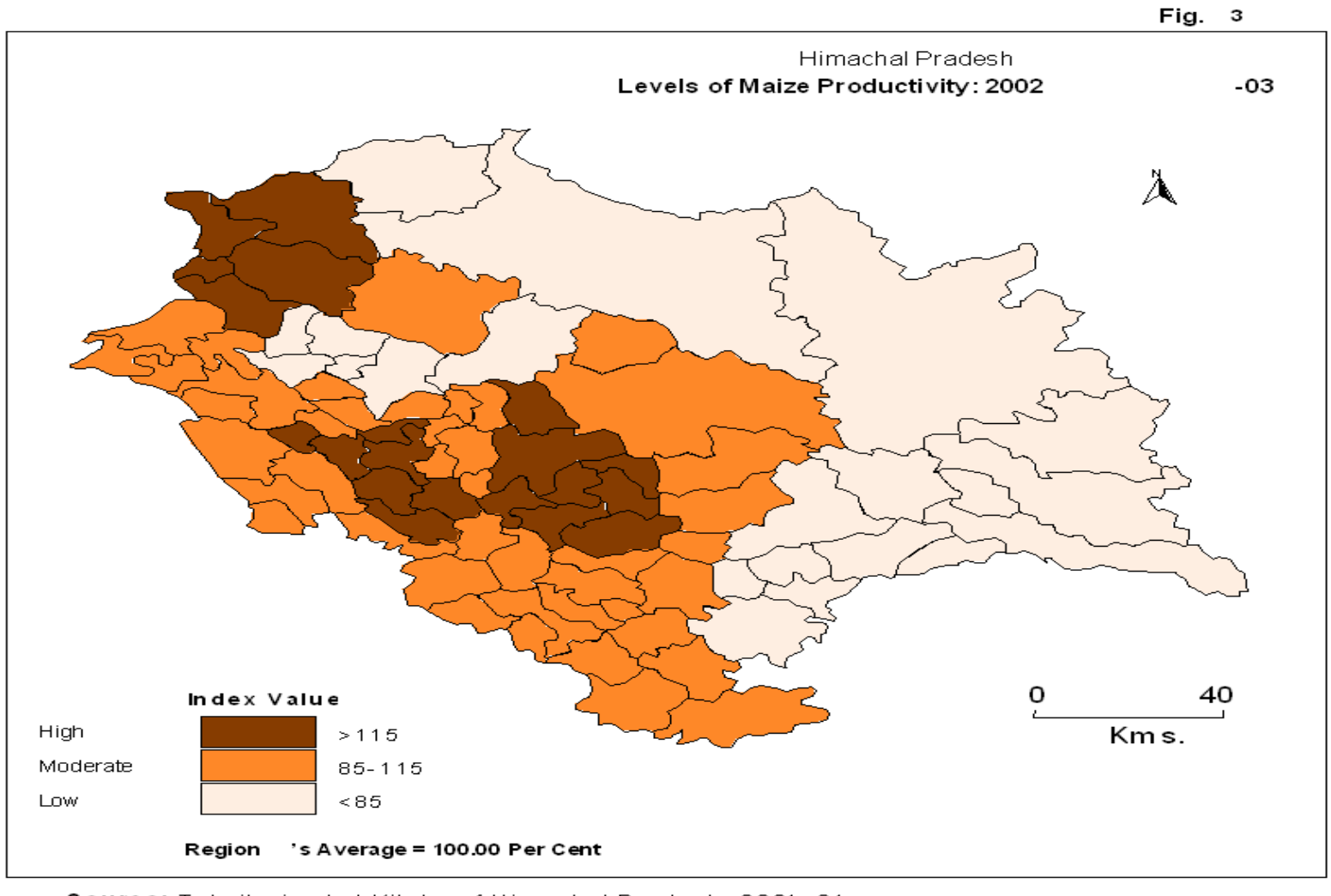

\section{Areas of Moderate Magnitude of Maize Productivity (85-115 index value):}

44 tehsils formed category of moderate levels of maize productivity, which had 51.76 percent of the total occurrences and was the largest category in size. It was largely confined to western and central parts of Himachal Pradesh. It had one belt and one patch. Reasons for moderate proportion in levels of maize productivity were presence of hills and piedmont areas with small mountains, low to high rainfall, lack of sufficient irrigation facilities, traditionally maize growing areas, hardly any cultivation of fruits and vegetables during summers, etc. particularly in the tehsils of Kangra, Una, Bilaspur, Hamirpur and Mandi district namely Bilaspur Sadar, Naina Devi ji, Bhoranj, Jawalamukhi, Khuniyan, Baroh, Nurpur, Indora, Jawali, Fatehpur, Jaswan Kotla, Dehra, Jaisinghpur, Jogindernagar, Lad-Bharol, Sandhol, Sarkaghat, Baldwara, Una, Amb, Bangana and Haroli. While in case of tehsils lied in south-western parts, the moderate proportion was largely owing to cultivation of rice in case of Paonta Sahib and Nahan tehsils, but other tehsils of Sirmaur and Solan districts and 5 tehsils of Shimla district namely Rampur, Kumarsain, Suni, Shimla $(R)$, Shimla $(U)$ and Theog, vegetables and fruits were responsible for moderate magnitude of maize productivity. Whereas in tehsils of Kullu district namely Kullu, Manali, Banjar and Nirmand, the moderate levels of maize productivity were owing to the cultivation of rice, fruits, vegetables, etc. Thus, all these factors became responsible for moderate index value of maize productivity. While in case of Bharmaur tehsils of Chamba district, the reason for moderate levels of maize productivity was some areas under rice which were adjoining to Palampur valley. But in central and upper parts of these tehsils, maize was predominant. Hence, these tehsils had recorded moderate magnitude of maize productivity. 


\section{Areas of Low Magnitude of Maize Productivity ( $<85$ index value):}

Only 21 tehsils had low level of maize productivity and reasons for low levels of maize productivity in case of Pangi, Lahaul and Spiti tehsils were mountainous areas with heavy snow, which hardly melt during summers, low temperature, less fertile soils, etc. did not allow the flourishing maize cultivation. Thus, low levels of maize productivity were found. Whereas in tehsils of Kinnaur district and western half of Shimla district namely Kalpa, Moorang, Pooh, Nichar, Sangla, Rampur, Kotkhai, Jubbal, Rohru, Chirgaon, Dodrakwar and Chopal, the index value of maize productivity was largely responsible for hilly to mountainous terrain, moderate to heavy snowfall, which generally melt during summers, etc. In such geo-climatic conditions, farmers preferred fruit plantation and wheat, millets and vegetables cultivation, etc. All these factors had led to low magnitude of maize productivity. But, in 6 tehsils of Kangra district tehsils namely Baijnath, Palampur, Dharmshala, Shahpur, Kangra and Nagrota Bagwan, where Palampur valley exists had gentle gradient of land, fertile soils, high rainfall, irrigation from kuhls, etc. created excellent conditions for cultivation of rice which was more remunerative than maize, thus farmers had preferred rice to maize, which led to low magnitude of maize productivity.

\section{Levels of Maize Productivity: 2014-15}

Magnitude of maize productivity in Himachal Pradesh during 2014-15 varies from 47.97 percent in Spiti tehsil to highest of 141.51 percent in Churah tehsil, which indicates very high range in the index value of maize productivity. There are different physical and socio-economic factors, which are responsible for these high variations, because these two major factors are heterogeneously distributed in the study region. For studying and understanding the uneven spatial patters in levels of maize productivity in Himachal Pradesh during 2014-15. Fig. 4 is mapped which exhibits three categories and an attempt is made to discuss these below:

\section{High Category of Maize Productivity Index Value (>115 percent):}

It contains 14 tehsils. It is found in three belts. First belt has seven tehsils of Hamirpur and Bilaspur districts which are namely Jandutta, Ghumarwin, Hamirpur, Barsar, Nadaun, Sujanpur and Rakkar. These are traditionally maize growing areas where its cultivation is done on shallow and moderate mountainous slopes, soils are suitable for its cultivation, temperature is quite high during May-June which is ideal for its growth followed by moderate to high rainfall supplemented by no water logging because of shallow and moderate slopes, stapple food, etc. These factors create ideal conditions for maize cultivation. Thus, farmers preferred it because rice which is another kharif crop cannot be grown successfully because of lack of adequate irrigation and hilly and mountainous terrain. Second belt comprised three tehsils of Chamba district and situated in north-western parts. These tehsils are Churah, Chamba and Salooni. These are remained dominant maize growing areas of Himachal Pradesh throughout the study period. Here, geo-climatic conditions and ideal for the growing of maize crop. Though, there is nearly absence of irrigation facilities, but high rainfall makes excellent conditions for its cultivation supplemented by stapled food and traditional maize growing areas, etc. As a result, this belt is remained as dominant maize growing areas of the study region. Third belt lies in four tehsils of Kullu and Mandi districts and namely Kullu, Banjar, Chchyot and Bali-Chowki. These areas were not maize dominant during in 1990-91 and 2002-03, but in 2014-15 these have become predominant maize growing areas and as a result both concentration and yield are recorded high which led to high magnitude of maize productivity.

\section{Moderate Category of Maize Productivity Index Value (85-115 percent):}

It is the largest category which lies in western half of the study region. 44 tehsils and 51.76 percent of total occurrences formed this category. There are different reasons in different tehsils 
which are responsible for moderate category of maize productivity. In case of Sirmaur district, its concentration index is moderate, because of the cultivation of rice and vegetables during summer season and resulted into moderate magnitude of maize productivity. But, in tehsils of Hamirpur, Una, Bilaspur and Kangra districts the reasons for high concentration are low to moderate rainfall, undulating, dissected, hilly and low mountains, high temperature, lack of irrigation facilities, etc. All these enthused the farmers to cultivate maize crop, which led to high concentration index of maize crop, but yield index of maize is found low to moderate, because of less fertile soils and as a result moderate index value of maize productivity is noted. But, in tehsils of Kullu and Mandi districts both concentration and yield index are found moderate. Moreover, in these districts, considerable area under either rice or vegetables or fruits is noted. Therefore, owing to all these factors in this part of the category, the levels of maize productivity are moderate.

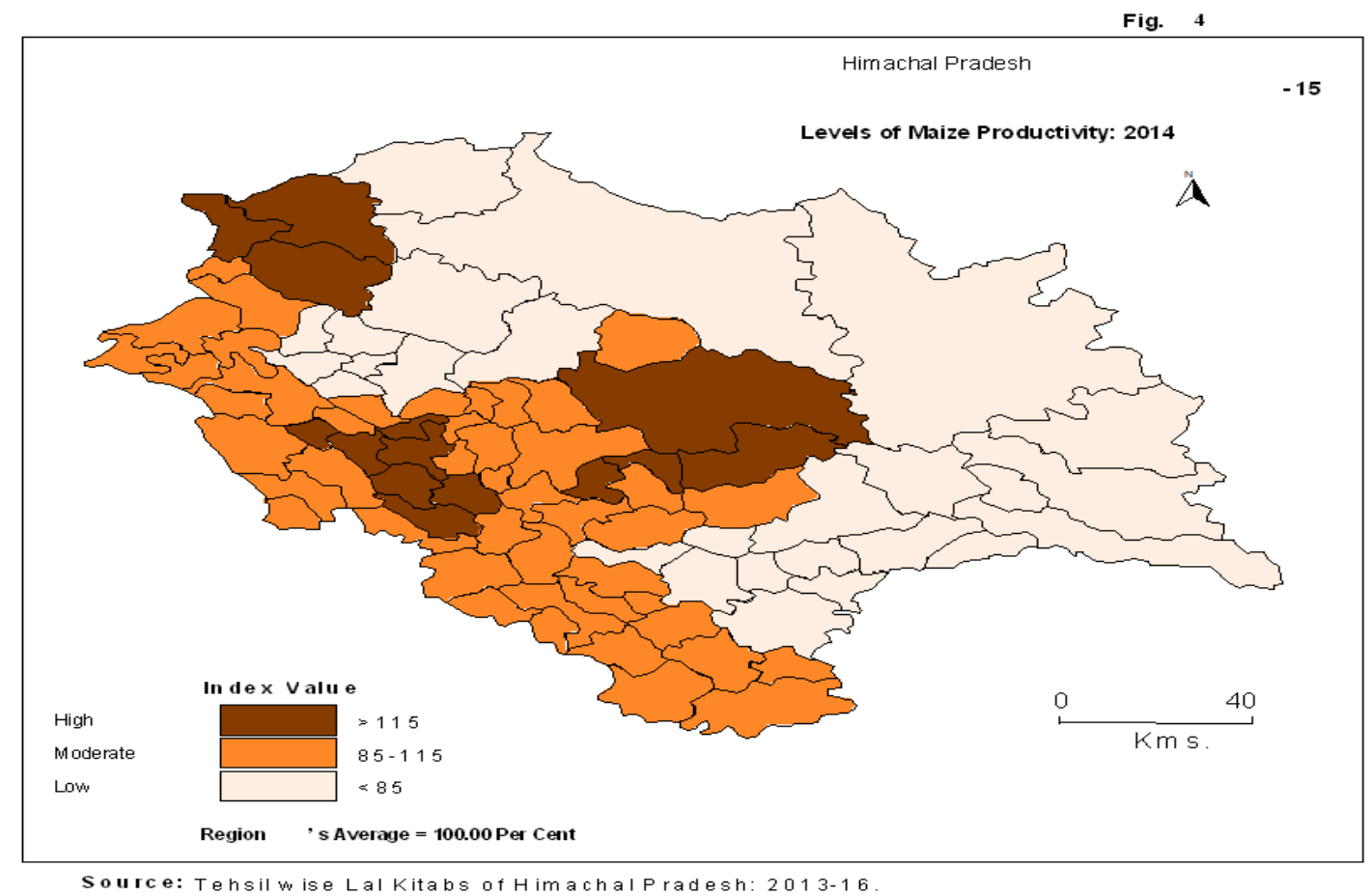

\section{Low Category of Maize Productivity Index Value (< 85 percent):}

In the category of low levels of maize productivity, there are 27 tehsils and

31.76 percent of the total occurrences. Here, in case of Pangi, Lahaul, Spiti, Kalpa, Moorang, Pooh, Nichar, Sangla, Rampur, Kumarsain, Suni, Theog, Kotkhai, Jubbal, Rohru, Chirgaon, Dodrakwar, Chopal and Karsog, the reasons for low levels of maize productivity are heavy snowfall and late melting of snow in summer season, low temperature, etc. do not allow healthy growth of maize crop, which require moderate to high temperature during its growing period. Thus, farmers in such temperate conditions and mountainous terrain grow vegetables, fruits, millets, etc. Owing to all these factors, area under maize is low which yield low concentration index and resulted into low magnitude of maize productivity. But, in case of tehsils of Bharmaur, Baijnath, Palampur, Dharmshala, Shahpur, Knagra, Nagrota Bagwan and Baroh, the low levels of maize productivity are owing to presence of Palampur valley, high rainfall, fertile soils, moderate to high temperature, high extent of irrigation, which is generally obtained from Kuhl irrigation, etc. In such conditions farmers preferred rice cultivation in kharif season as compare to maize, which led to very small proportion of small area under maize crop and led to low levels of maize productivity.

\section{Volume of Change in Levels of Maize Productivity: 1990-91 to 2014-15}

Changes in maize productivity are the combined result of changes in socio-economic and cultural factors supplemented by leveling of some land near Shiwaliks etc. For explaining spatio-temporal 
changes in levels of maize productivity, help is taken from figures 2 to 4 and tables 1 and 2 which yield the following points:

1. In 1990-91, the category of high magnitude of maize productivity was largely confined to northwestern and south-western parts, but in 2002-03 some tehsils of south-western parts of high category had joined the category of moderate maize productivity, while high category of maize productivity shifted to central-western parts by capturing two tehsils of each Mandi and Bilaspur districts which had moderate productivity in 1990-91. North-western belt of high category had expanded in its size and the number of tehsils increased from 4 to 5 during 1990-91 to 2002-03. But overall number of tehsils had declined from 21 to 20 during 1990-91 to 2002-03. While during 2002-03 to 2014-15, the north-western belt of high category has seen decrease in its number of tehsils from 5 to 3 . But central belt has shifted towards east capturing 2 tehsils namely Kullu and Banjar of Kullu district, where the level of maize productivity was moderate in 2002-03, whereas loss of some tehsils in western Kullu and Mandi districts. Though the belt of high category which lies in the tehsils of Hamirpur and Bilaspur districts has remained almost the same. Hence during 2002-03 to 2014-15, number of tehsils in high category has declined from 20 to 14.

2. The moderate category had 41 tehsils in 1990-91, which increased to 44 in 2002-03 and gained 3 tehsils which were snatched from both low and high categories. But the number of tehsils in moderate category had remained same from during 2002-03 to 2014-15. Whereas, the number of tehsils during 1990-91 to 2014-15 in moderate category has increased from 41 to 44 .

3. Low category of maize productivity had lost 2 tehsils during 1990-91 to 2002-03 to the category of moderate magnitude. The major areas of this category had remained almost same which were lying in tehsils of the districts of Kinnaur, Shimla, Lahaul \& Spiti, Kangra and Chamba. But in 2014-15, the number of tehsils has increased, because 4 tehsils of moderate category namely Bharmaur, Suni, Karsog and Theog have shifted from moderate to low category, owing to shift of area from maize to fruits and vegetables and consequently the number of tehsils has increased from 21 to 27 during 2002-03 to 2014-15.

4. Overall spatio-temporal changes during 1990-91 to 2014-15 have noted some changes in levels of maize productivity. The seven tehsils of high category ( $>115$ index value) have shifted to moderate category. While central parts of moderate category which include tehsils of Kullu, Banjar, Chchyot, Bali-Chowki have shifted from high category to moderate category. Whereas, Bharmaur, Suni, Karsog, Baroh and Jawalamukhi tehsils have transferred from moderate to low. While Manali tehsil has shifted from low to moderate. As a result of these changes, the number of tehsils in high category has declined from 21 to 14, tehsils of moderate category have increased from 41 to 44 and tehsils in low category have increased from 23 to 27 during 1990-91 to 201415.

5. During study period in Himachal Pradesh, the highest index value of maize productivity has declined from 150.90 percent in 1990-91 to 143.14 percent in 2002-03 and further decreased to 141.15 percent in 2014-15, thus recorded a decrease of 6.76 index value during 1990-91 to 200203, 1.63 index value during 2002-03 to 2014-15 and overall negative change of 8.39 index value during 1990-91 to 2014-15. Whereas the lowest index of overall maize crop productivity was 47.55 percent, 47.45 percent, and 47.97 percent during 1990-91, 2002-03 and 2014-15 respectively. Thus, the low index of maize productivity has experienced a decline of 0.10 percent during 199091 to 2002-03, but increase of 0.52 percent during 2002-03 to 2014-15 and as a result overall positive change of 0.42 percent during study period.

Hence, these changes in overall maize productivity index value indicate that gap between the high and low magnitude of maize productivity has reduced over study period in the state, which means gap in regional disparities in levels of maize productivity have minimized and it is a sign of healthy maize cultivation. 
Table 02: Changes in Levels of Maize Crop Productivity: 1990-91 to 2014-15

\begin{tabular}{|c|c|c|c|c|c|c|c|c|c|}
\hline \# & Tehsils & $\begin{array}{l}\text { Change } \\
1990-91 \\
\text { to } 2002-03 \\
\end{array}$ & $\begin{array}{l}\text { Change } \\
2002-03 \text { to } \\
2014-15\end{array}$ & $\begin{array}{l}\text { Change } \\
1990-91 \text { to } \\
2014-15\end{array}$ & $\#$ & Tehsils & $\begin{array}{l}\text { Change } \\
1990-91 \text { to } \\
2002-03\end{array}$ & $\begin{array}{l}\text { Change } \\
2002-03 \text { to } \\
2014-15 \\
\end{array}$ & $\begin{array}{l}\text { Change } \\
1990-91 \text { to } \\
2014-15 \\
\end{array}$ \\
\hline 1 & Bilaspur Sadar & -5.68 & -36.17 & -41.85 & 44 & Spite & -10.94 & 10.51 & 0.42 \\
\hline 2 & Jandutta & 10.24 & 7.59 & -17.83 & 45 & Mandi & 8.64 & -24.15 & -15.51 \\
\hline 3 & Naina Devi ji & -12.66 & -15.09 & -27.75 & 46 & Sundernagar & 3.24 & -14.34 & -11.1 \\
\hline 4 & Ghumarwin & 8.61 & 4.14 & 12.75 & 47 & Sarkaghat & 4.94 & -14.39 & -9.45 \\
\hline 5 & Pangi & -3.66 & -9.47 & -13.13 & 48 & Jogindernagar & 8.31 & -13.4 & -5.09 \\
\hline 6 & Churah & -7.76 & -1.63 & -9.39 & 49 & Karsog & 16.47 & -4.83 & 11.64 \\
\hline 7 & Chamba & -1.55 & -2.77 & -4.32 & 50 & Chchyot & 12.09 & -3.43 & 8.66 \\
\hline 8 & Salooni & -6.29 & -6.83 & -13.12 & 51 & Thunag & 9.61 & -10.94 & 1.33 \\
\hline 9 & Dalhousie & -8.8 & -19.64 & -28.44 & 52 & Baldwara & 5.29 & -18.73 & -13.44 \\
\hline 10 & Bhattiyat & 6.8 & -7.56 & -0.76 & 53 & Bali Chowki & 15.57 & -0.45 & 15.12 \\
\hline 11 & Bharmaur & -10.68 & -43.04 & -53.72 & 54 & Sandhol & -8.7 & -4.93 & -13.63 \\
\hline 12 & Hamirpur & 9.76 & 10.88 & 20.64 & 55 & Paddhar & 5.88 & -13.46 & -7.58 \\
\hline 13 & Bhoranj & -9.9 & 21.97 & 12.07 & 56 & Nihri & 19.78 & -11.63 & 8.15 \\
\hline 14 & Barsar & 3.33 & -8.95 & -5.62 & 57 & Lad-Bharol & -7.54 & 2.69 & -4.85 \\
\hline 15 & Nadaun & 2.93 & -11.24 & -8.31 & 58 & Rampur & 5.61 & -13.61 & -8 \\
\hline 16 & Sujanpur & -29.42 & -2.32 & -31.74 & 59 & Kumarsain & 1.94 & -25.41 & -25.41 \\
\hline 17 & Baijnath & -15.59 & -5.03 & -20.62 & 60 & Suni & -5.73 & -35.27 & -35.27 \\
\hline 18 & Palampur & -7.98 & -3.32 & -11.3 & 61 & Shimla (R) & 7.46 & -22.37 & -22.37 \\
\hline 19 & Jaisinghpur & -0.47 & -0.25 & -0.72 & 62 & Shimla (U) & 7.37 & -23.94 & -23.94 \\
\hline 20 & Dharmshala & -9.16 & -3.76 & -12.92 & 63 & Theog & -8.73 & -21.32 & -21.32 \\
\hline 21 & Shahpur & 0.76 & -4.86 & -4.1 & 64 & Kotkhai & -11.22 & -11.51 & -11.51 \\
\hline 22 & Nurpur & 10.03 & -0.59 & 9.44 & 65 & Jubbal & 5.58 & -20.94 & -15.36 \\
\hline 23 & Indora & 11.12 & -7.49 & 3.63 & 66 & Rohru & 2.21 & -20.38 & 18.17 \\
\hline 24 & Jawali & -0.27 & -0.5 & -0.77 & 67 & Chirgaon & -9.09 & -11.42 & -2.33 \\
\hline 25 & Fatehpur & -1.5 & -0.94 & -2.44 & 68 & Dodrakwar & 5.42 & -6.16 & -0.74 \\
\hline 26 & Dehra & -6.46 & -2.22 & -6.68 & 69 & Chopal & 0.79 & -7.38 & 5.19 \\
\hline 27 & Jaswan Kotla & -9.56 & -10.57 & -20.13 & 70 & Nahan & -16.46 & 5.19 & -11.27 \\
\hline 28 & Rakkar & 0.17 & 3.22 & 3.39 & 71 & Paonta Sahib & -26.44 & -4.74 & -31.18 \\
\hline 29 & Jawalamukhi & -5.99 & 1.85 & -4.14 & 72 & Pachhad & -23.26 & -6.53 & -29.79 \\
\hline 30 & Khundiyan & -1.55 & 1.36 & -0.19 & 73 & Rajgarh & -25.59 & -3.35 & -28.94 \\
\hline 31 & Kangra & -3.28 & -5.81 & -9.09 & 74 & Shillai & -18.42 & 5.12 & -13.3 \\
\hline 32 & $\begin{array}{l}\text { Nagrota } \\
\text { Bagwan }\end{array}$ & -13.26 & -7.97 & -21.23 & 75 & Renuka ji & -20.83 & 5.83 & -15 \\
\hline 33 & Baroh & -6.08 & -27.4 & -33.48 & 76 & Solan & -30.17 & 2.3 & -27.87 \\
\hline 34 & Kapla & -1.53 & -6.8 & -8.33 & 77 & Nalagarh & -15.44 & -5.36 & -20.8 \\
\hline 35 & Moorang & 0.13 & -3.11 & -2.98 & 78 & Kasauli & -12.53 & -1.98 & -14.51 \\
\hline 36 & Pooh & 1.58 & -1.95 & -0.37 & 79 & Baddi & -20.12 & 6.07 & -14.05 \\
\hline 37 & Nichar & 1.1 & -2.63 & -1.53 & 80 & Arki & -27.76 & 10.23 & -17.53 \\
\hline 38 & Sangla & -9.87 & -2.2 & -12.07 & 81 & Kandaghat & -19.43 & -14.69 & -34.12 \\
\hline 39 & Kullu & 7.46 & 31.09 & -38.55 & 82 & Una & -18.96 & 10 & -8.96 \\
\hline 40 & Manali & 8.44 & 6.07 & 14.51 & 83 & Amb & 1.21 & -0.82 & 0.39 \\
\hline 41 & Banjar & 14.65 & 10.43 & 25.08 & 84 & Bangana & -2.34 & -0.29 & -2.63 \\
\hline 42 & Nirmand & 9.55 & 2.72 & 12.27 & 85 & Haroli & -11.27 & 1.14 & -10.13 \\
\hline
\end{tabular}

Source: Tehsil Wise Lal Kitabs of Himachal Pradesh: 1989-92, 2001-04 and 2013-16.

\section{Conclusion}

In 1990-91, the index value of maize productivity varied from 47.55 percent in Spiti tehsil to 155.90 percent in Churah tehsil in study area. While in 2002-03, index value of crop productivity was also variable which ranged from 47.45 percent in Lahaul tehsil to 143.14 percent in Churah tehsil. Whereas, magnitude of maize productivity in Himachal Pradesh during 2014-15 lies between lowest of 47.97 percent in Spiti tehsil and highest of 141.51 percent in Churah tehsil. During study period in Himachal Pradesh, the highest index value of maize productivity has declined from 150.90 percent in 1990-91 to 143.14 percent in 2002-03 and further decreased to 141.15 percent in 2014-15, thus recorded a fall of 6.76 index value during 1990-91 to 2002-03, 1.63 index value during 2002-03 to 2014-15, but overall study period has experienced a negative change of 8.39 index value. Whereas the lowest index value of overall maize crop productivity was 47.55 percent, 47.45 percent, and 47.97 percent during 1990-91, 2002-03 and 2014-15 respectively and noted positive change of 0.42 percent. All this show that regional disparities in maize productivity have 
minimised during present period of investigation. Spatially, patterns of maize productivity magnitude decrease from south-west to north-east direction and coincide with the patterns of relief, temperature, irrigation, road density, etc.

\section{References}

1. Ali, M.J. and Ali, M. (2007). "Levels of Agricultural Development in Malda District, West Bengal" Geographical Review of India, Vol.69, No.2, pp. 178-186.

2. Chatterji and Maitreya (1964). "Some Aspects of Regional Variations in Agricultural Productivity and Development in West Bengal", Indian Journal of Agricultural Economics, Vol.19, No.1, pp.207-212.

3. Hussain, M. (2009). "Systematic Agriculture Geography" Rawat Publication, Jaipur, pp.2162, 90, 93-117, 122-131, 200, 217, 222, 245.

4. Munir, A. (1988). "Agricultural Productivity and Regional Development-A Case Study of the Sub-Himalayan East Region of Uttar Pradesh", The Geographer, Vol.35, No.2, pp.45-59.

5. Prasad, A. R. and Tripathi, A. (2008). "Agricultural Productivity Growth in India", Journal of Global Economy an International journal.

6. Saddiqui, S. H. \& Taufique, M. (2005). "Spatial Patterns of Agricultural Productivity in NorthBihar Plain Using Yangs Method", National Geographer, Vol, XL, No. 1 \& 2, p-67.

7. Singh, J. (1976), "An Agricultural Geography of Haryana" Vishal Publications, University Campus Kurukshetra, p. 299.

8. Singh, R.B. (1998). "Impact of Agriculture and Land use / Cover Change of Soil and Water Resources and Ecosystem Sustainability- A Case Study of Punjab", The Geographer, Vo. 45, No.2, pp. 93-118.

9. Sohal, K.S.(2004). "Regional Disparities in Crop Productivity in Punjab, India", National Geographer, Vol.25, No.2, pp.107-114.

10. Tehsil Wise Lal Kitabs of Himachal Pradesh:1989-92,2001-04 and 2013-16. 